\title{
Experimental Research on Performance and Emission Characteristics of Country Borage Methyl Ester - Diesel Blend in a Compression Ignition Engine
}

\author{
Anbarasan B , Venkatesh J, Jamunarani M
}

\begin{abstract}
An Experiment has been conducted performance and emission and combustion characteristics of a single-cylinder by using country borage methyl ester (CBM) and diesel blend in a direct injection at a constant speed diesel engine. In the past few years, the investigation on the biofuels has been considerable interest by virtue of their unique physical and chemical properties. This experiment works involves the usage of country borage methyl ester and diesel blend, to study its effect on performance, combustion and emission characteristics. Diesel and country borage methyl ester fuel blends are $20 \%, 40 \%$, 60\%, $80 \%$, 100\%, and varying load of $25 \%$ increment from no load to full load. The experiment was carried out for engine performance parameter such as brake thermal efficiency (BTE) of CBM 20 blend was slightly higher 3\% than that of diesel. And the engine emission parameters such as hydrogen emissions is reduced $22 \%$ for CBM 20 and $32.5 \%$ for CBM 40 blend. And NOx emission was slightly increased by 5\% for CBM 20 and $8 \%$ for CBM 40.
\end{abstract}

\section{Keywords: Biodiesel, Performance, Emission, Engine}

\section{INTRODUCTION}

The fossil fuels are less expensive as compared to biofuels. The widespread use of biodiesel blend with diesel is used in CI engines. In recent years many kinds of research to determine the suitability of vegetable oil and its derivatives as fuel are additives to the diesel. Reducing emissions in the automobile sector is one of the most important issues, initiate to develop the biofuels such as the recent studies by Jatropa, Soaknut, Mahua oil, Kapok oil, Papaya seed oil and country borage oil were compared with standard diesel properties and using this biodiesel to study the emission of the engine. Misra and Murthy (2011) have investigated the blend of diesel and soaknut oil $10 \%, 20 \%, 30 \%$, and $40 \%$ were used to conduct the performance and emission characteristics at varying loading in terms of $25 \%$ increment to no load to full load. In this test engine, the performance parameter is brake thermal efficiency, specific fuel consumption and exhaust emissions

Revised Version Manuscript Received on August 19, 2019.

Anbarasan B, Assisstant professor,Department of Mechanical Engineering,PSNA College of Engineering and Technology, Dindigul, Tamil Nadu India(Email: : anbarasan5mech@gmail.com)

Venkatesh J, Assisstant professor,Department of Mechanical Engineering,PSNA College of Engineering and Technology, Dindigul, Tamil Nadu India(Email: : mechanicalmechivenkat@gmail.com)

Jamunarani M, Assisstant professor,Department of Mechanical Engineering,PSNA College of Engineering and Technology, Dindigul, Tamil Nadu India(Email: : jamuna.aero@gmail.com) were recorded. Among the blends, SNO 10\% has a better performance of BTE. The emission of $\mathrm{HC}$ is increased at $75 \%$ low and emission of $\mathrm{CO}$ is lower at full load. NOx emissions for all blend $35 \%$ reduction. Combustion characteristics were analyzed in CI engine fueled with diesel the maximum cylinder pressure the ignition delay, the premixed combustion duration and the fraction of heat released in premixed combustion phase will increase, while the diffusive combustion phase. SukumarPuhan and Vedaraman (2005) have studied the vegetable oil can be used in diesel engine in high viscosity low volatilities, poor cold properties have to lead to the various investigative derivatives. The biodiesel was tested in a single cylinder, four strokes, direct injection at a constant speed to evaluate the performance and emission of Mahua oil. The specific fuel consumption(20\%) is higher than that of diesel and thermal efficiency $(13 \%)$ is lower than that of diesel. The exhaust emission of $\mathrm{CO}$ is $30 \%$ reduced compared to the diesel, $\mathrm{HC}$ is $35 \%$ reduced, the smoke number is reduced by $11 \%$ and oxide of nitrogen by $4 \%$. LeenusJesu Martin and Edwin Geo (2012). In this study the viscosity of cottonseed oil, which has been considered as alternative fuels for a compressive ignition engine. The blends of varying proportions of cotton seed oil and diesel were prepared and analyzed and compared with performance and emissions of the single-cylinder diesel engine. The performance was observed a neat cotton seed oil is slightly increased compared to standard diesel engine and emissions of $\mathrm{CO}, \mathrm{HC}$ is reduced and NOx was increased. Muralidharan $\mathrm{K}$, Vasudevan D et al (2011). In this study the performance and emission and combustion characteristics of a single-cylinder, four strokes variable compression ratio with waste cooking and its diesel blends. The performance parameters are analyzed with standard diesel it conforms considerable improvements in the performance parameters and exhaust emissions. The emission of $\mathrm{CO}, \mathrm{HC}, \mathrm{CO} 2$ were reduced and NOx emission was increased and combustion characteristics of waste cooking oil and, methyl ester and diesel blends were closely followed those of standard diesel.

\subsection{Country Borage Oil}

This oil is extracted from country borage leaves. It is available in our country. Its properties are approximately the

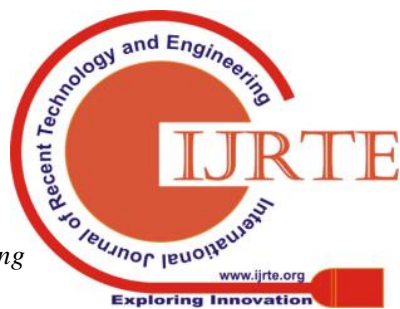


Experimental Research on Performance and Emission Characteristics of Country Borage Methyl Ester - Diesel Blend in a Compression Ignition Engine

same to diesel properties. Performance emission characteristics are to be tested using this oil is non-edible oil. This oil has been considered as an alternative fuel for the compression. And it has low viscosity oil compare than other biodiesel, moisture content also less in this oil.

The blends of varying proportions of country borage oil and diesel will be prepared, analyzed and compared with the performance of diesel fuel and studied using a single cylinder C.I. engine.

\section{EXPERIMENT LAYOUT}

The layout of the experimental setup is shown in figure 2.1 and the specification of the engine is given in table.2.1

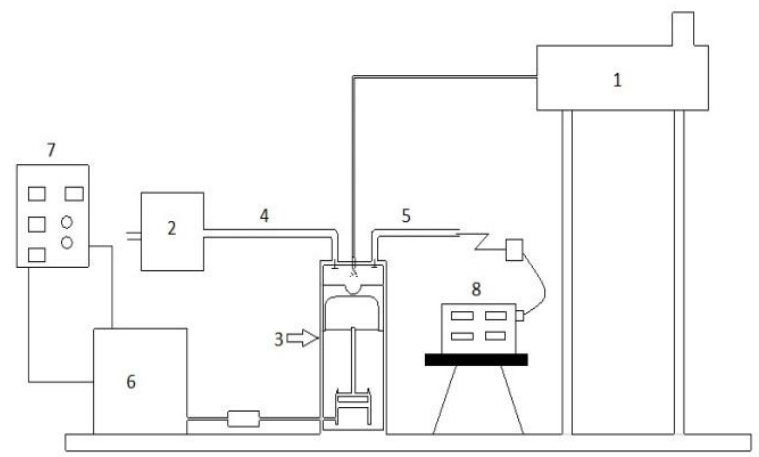

Fig 2.1 Schematic Diagram of the Experimental setup
1. Fuel tank
5. Exhaust
2. Surge tank
6. Eddy current
3. Engine dynamometer
4. Inlet
7. Load cell
8. Exhaust gas analyzer

\begin{tabular}{|l|l|}
\hline Model & Kirloskar TAF-1 \\
\hline Type & $\begin{array}{l}\text { Single cylinder, four strokes, } \\
\text { direct injection }\end{array}$ \\
\hline Piston Type & Bowl-in-piston \\
\hline Capacity & $660 \mathrm{cc}$ \\
\hline Bore x stroke & $87.5 \mathrm{~mm}$ x 110mm \\
\hline Compression Ratio & $17.5: 1$ \\
\hline Speed & $1500 \mathrm{rpm}$ (constant) \\
\hline Rated Power & $4.4 \mathrm{~kW}$ at $1500 \mathrm{rpm}$ \\
\hline Dynamometer & Electrical type \\
\hline Cooling system & Air cooling \\
\hline Injection Timing & $23^{\circ} \mathrm{C} \mathrm{Btdc}$ \\
\hline Injection Pressure & 200 bar \\
\hline Ignition & Compression-Ignition \\
\hline
\end{tabular}

Table 2.2 Properties of country borage oil

\begin{tabular}{|l|l|}
\hline Properties & $\begin{array}{c}\text { Indian borage } \\
\text { oil }\end{array}$ \\
\hline Density $\left(\mathrm{kg} / \mathrm{m}^{3}\right)$ & 910 \\
\hline Viscosity $($ at $40 \circ \mathrm{C})(\mathrm{cs})$ & 5.2 \\
\hline Flashpoint $\left({ }^{\circ} \mathrm{C}\right)$ & 95 \\
\hline Fire point $\left({ }^{\circ} \mathrm{C}\right)$ & 110 \\
\hline Free fatty acid $(\%)$ & 1.8 \\
\hline Moisture content $(\%)$ & 10.8 \\
\hline pH value $\left(\right.$ at $\left.25^{\circ} \mathrm{C}\right)$ & 6.5 \\
\hline
\end{tabular}

Table 2.3 Comparisons of fuel properties

\begin{tabular}{|l|l|l|l|l|}
\hline Properties & Diesel & $\begin{array}{l}\text { Country } \\
\text { borage oil } \\
\text { oil }\end{array}$ & $\begin{array}{l}\text { Jatropha } \\
\text { oil }\end{array}$ \\
\hline $\begin{array}{l}\text { Density } \\
\left(\mathrm{kg} / \mathrm{m}^{3}\right)\end{array}$ & 840 & 910 & 918 & 912 \\
\hline $\begin{array}{l}\text { Viscosity (at } \\
40 \circ \mathrm{C})\end{array}$ & 4.9 & 5.2 & 7.9 & 7.2 \\
\hline $\begin{array}{l}\text { Flash point } \\
\left({ }^{\circ} \mathrm{C}\right)\end{array}$ & 61 & 95 & 186 & 134 \\
\hline $\begin{array}{l}\text { Fire point } \\
\left({ }^{\circ} \mathrm{C}\right)\end{array}$ & 64 & 110 & 210 & 160 \\
\hline $\begin{array}{l}\text { Free fatty } \\
\text { acid (\%) }\end{array}$ & 0.2 & 1.8 & 5.31 & 0.5 \\
\hline $\begin{array}{l}\text { Moisture } \\
\text { Content }(\%)\end{array}$ & $\mathrm{Nil}$ & 10.8 & 15 & 14 \\
\hline
\end{tabular}

\section{RESULTS AND DISCUSSION}

\subsection{Performance Analysis}

The variation of cylinder pressure with the crank angle for the country borage and its diesel blends. The cylinder peak pressure decreases as the proportion of country borage methyl ester in the blend increases but CBM 20 is slight increases compared to diesel and all other blends of cylinder pressure are lower than the diesel.

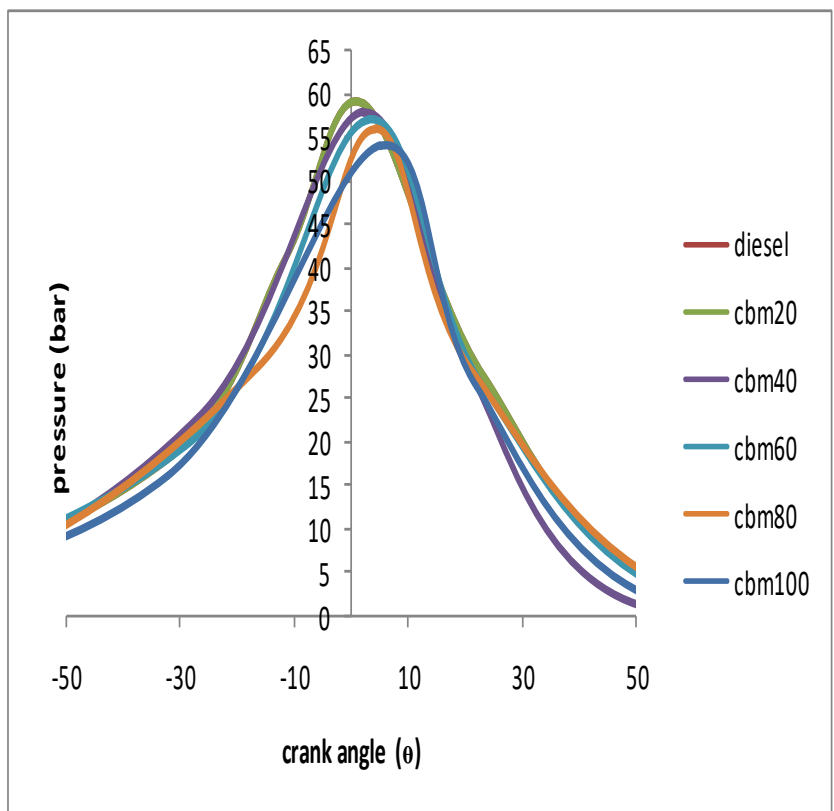

Fig.3.1.1 Variation of pressure with the crank angle at full load

Published By: 


\subsubsection{Rate Of Heat Release}

Fig. 3.1.2 Shows the comparison of heat release of country borage and its diesel blends. Country borage methyl ester blends are lower in premixed heat release compared that of standard diesel because the lower heating value of CBM blend as the percentage of CBM blends increases. The maximum heat release rate decreases it is absorbed that the ignition delay of the CBM and its diesel blends are lower than that of diesel. As a result of high in-cylinder temperature during fuel injection, biodiesel may undergo thermal cracking as a result of this.

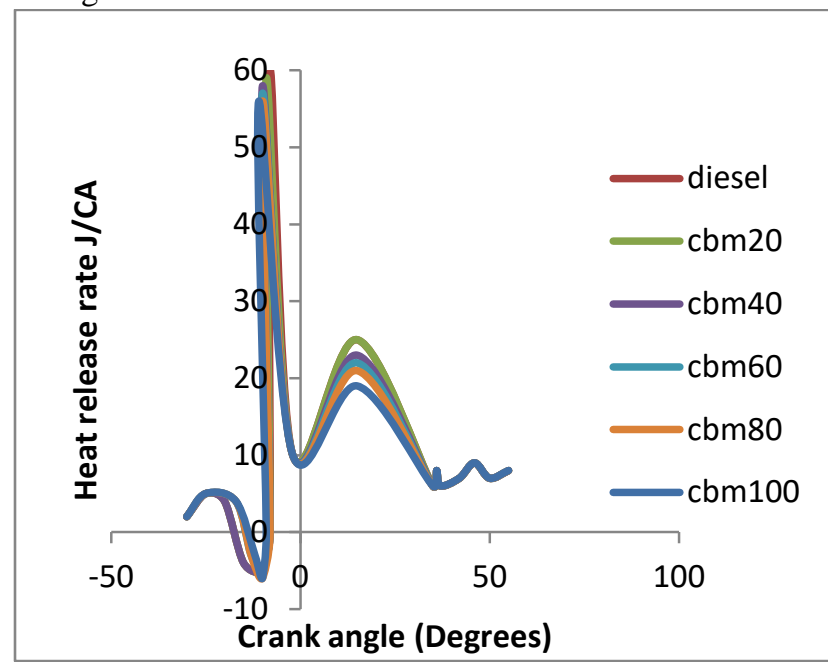

Fig. 3.1.2 Heat Release Rate with Crank angle.

\subsection{Performance Analysis}

\subsubsection{Brake Thermal Efficiency}

The brake thermal efficiency of country borage methyl ester and its diesel blend as shown in figure 3.2.1. The brake thermal efficiency for CBM 20 is $3 \%$ higher than the diesel and CBM 40 is near to diesel and remaining blends are lower than the diesel because it is an oxidation fuel so that combustion takes place completely. That's why BTE is increased. The decrease for brake thermal efficiency for higher blends due to lower heating value and higher viscosity of blends with a high proportion of methyl ester.

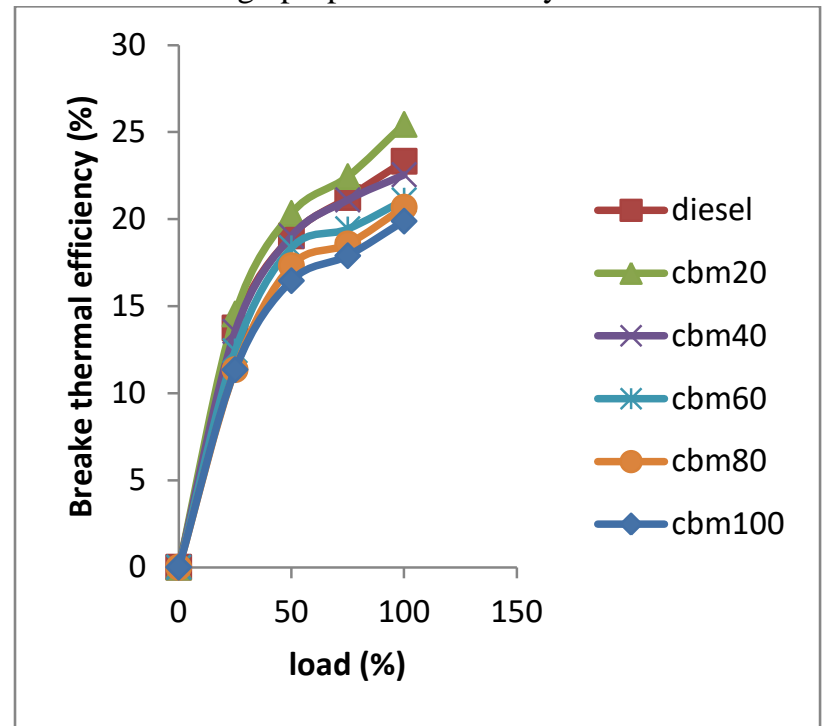

Fig. 3.2.1 Variation of Brake Thermal Efficiency with load

\subsection{Emission Analysis}

\subsubsection{Carbon Monoxide Emissions}

The CO emissions are increased in low load and higher load and decreased in medium load. In no-load high $\mathrm{CO}$ because the cylinder temperature is low. After that, the temperature is increased in the cylinder $\mathrm{CO}$ is reduced. In high load due to insufficient oxygen, so fuel is not burned completely, so the $\mathrm{CO}$ emission is high.

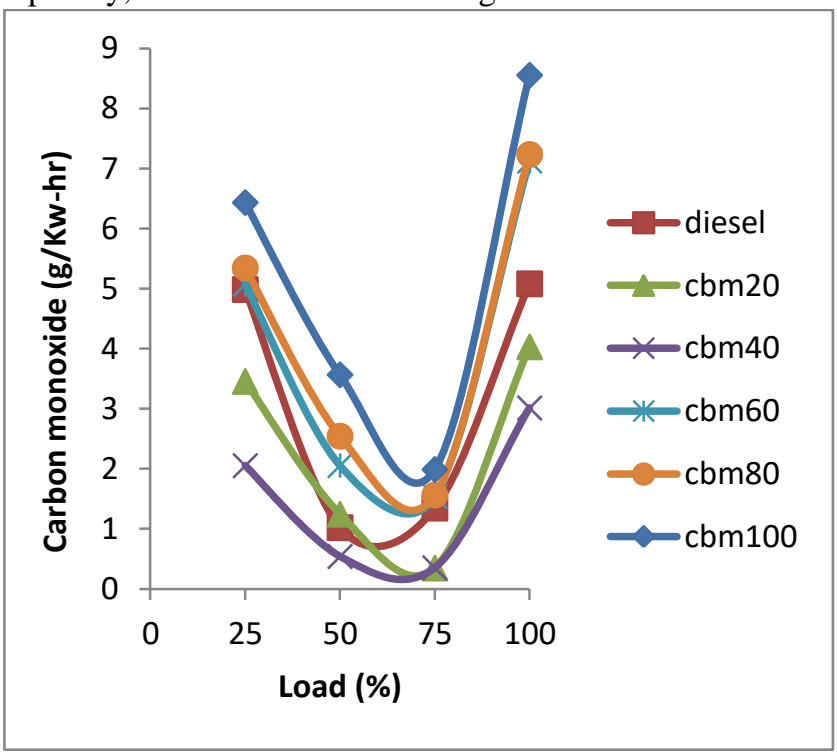

Fig.3.3.1 Variation of Carbon monoxide with a load

\subsubsection{Hydro Carbon emissions}

The variation of $\mathrm{HC}$ emission with a load is shown in figure 3.3.2. The $\mathrm{HC}$ emission is high at $25 \%$ and $100 \%$ load. In medium load, the HC is very low. The CBM 20 is lower than that of diesel. In no-load and high load combustion is not completely take place due to insufficient oxygen. In medium load, the combustion takes place completely because of sufficient oxygen. The effect of fuel viscosity and spray quality has been expected to produce some hydrocarbon increased. Due to the longer ignition delay, the combustion chamber may cause a higher $\mathrm{HC}$ emission.

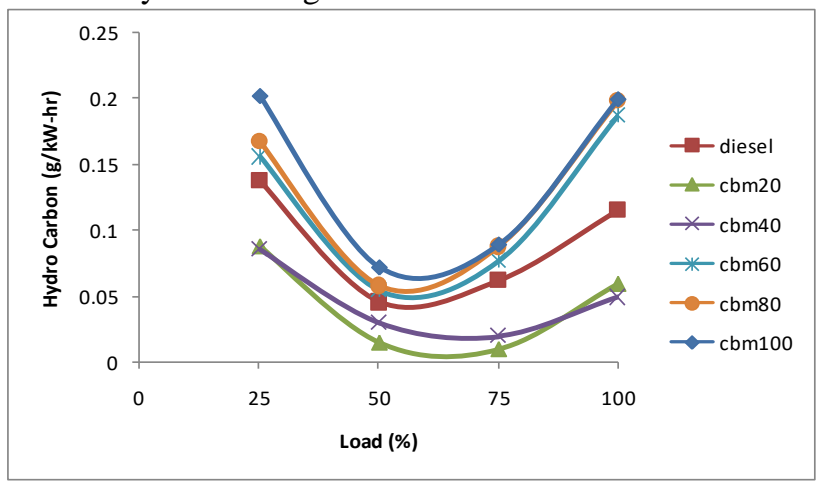

Fig.3.3.2. Variation of Hydro Carbon with a load

\subsubsection{Oxides of nitrogen (NOx)}

Variation of NOx emission with a load of country borage methyl ester and its diesel blends. It was observed that emission increased by $5 \%$ for CBM 40 and $8 \%$ for CBM 100 for a full load. In spite of higher viscosity of methyl ester and

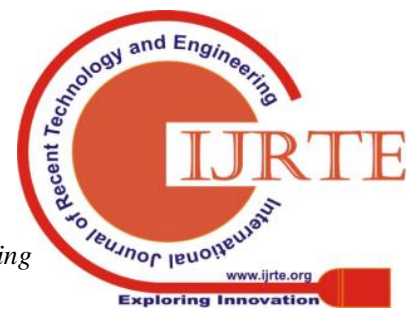


ignition delay to be lowered than that of diesel. The shorter ignition delay for biodiesel also may advance the start of combustion and contribute to higher $\mathrm{NO}_{\mathrm{X}}$ emission, in addition, the oxygen present in the fuel additional oxygen for NOx emission. Thereby increase the NOx emission. The reason for higher NOx emission for the blend is due to the higher peak temperature.

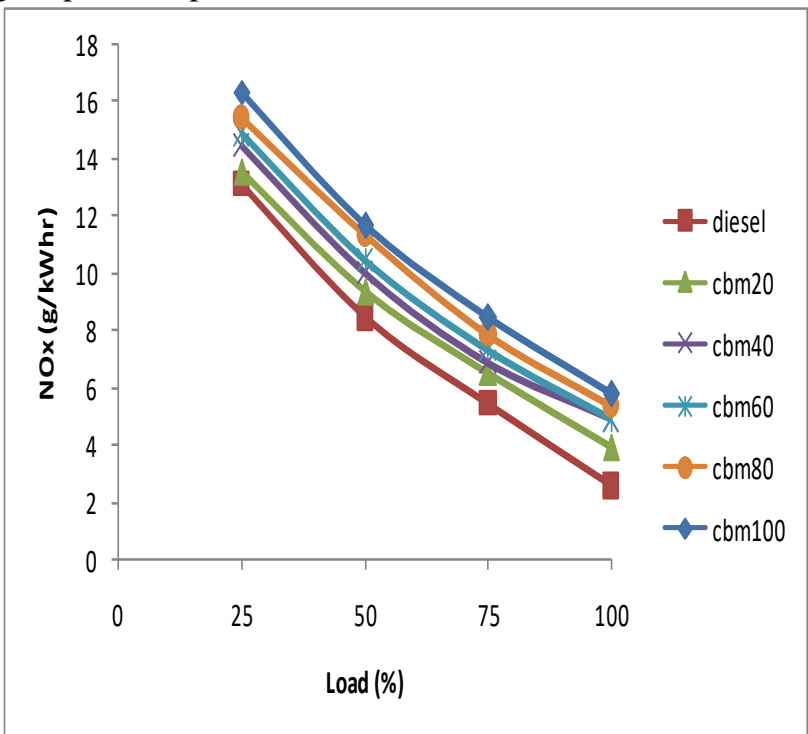

Fig 3.3.3 Variation of Oxides of nitrogen with a load

\subsubsection{Smoke Opacity}

The variation of smoke opacity is shown in figure 3.3.4. The CBM 20 is lower smoke opacity compared to that of diesel and CBM 100 is higher smoke opacity. The smoke opacity is gradually increased for all other blends due to insufficient oxygen, incomplete combustion takes place. This may be due to the presence of an oxygen molecule in the methyl ester, which enables more complete combustion.

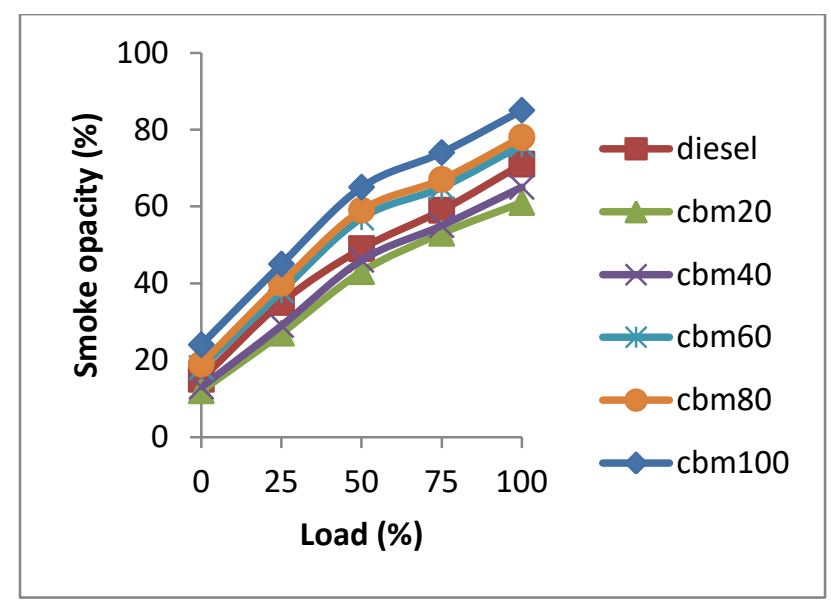

Fig 3.3.4 Variation of Smoke opacity with a load

\subsubsection{Exhaust Gas Temperature}

The variation of exhaust gas temperature with a load for country borage methyl ester and its diesel blend. It absorbed exhaust gas temperature also increase for all the loads. In no-load the exhaust gas temperature is low. Increase the load the exhaust gas temperature increases due to more oxygen content in CBM which improves combustion and thus increase the exhaust gas that as a proportion of methyl ester increase in a blend the

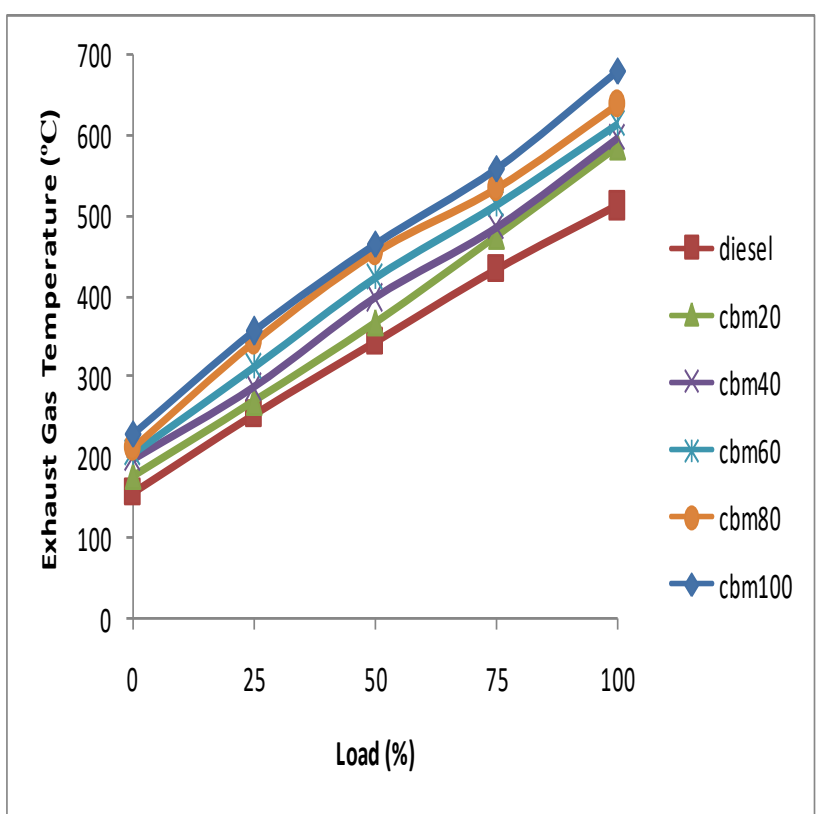

Fig.3.3.5 Variation of Exhaust gas temperature with a load

\section{CONCLUSION}

The performance, emission and combustion characteristics of a $4.4 \mathrm{~kW}$ DI compression ignition engine summer with cbm and its blends have been analyzed and compared to those of diesel fuel. The conclusion of the present work is summarized as follows.

$>$ The BTE of CBM 20 blend was slightly higher $3 \%$ of standard diesel.

$>$ The reduction of $\mathrm{HC}$ emission by $22 \%$ and $23 \%$ respectively were recorded for the CBM 20 blend and CBM 40 blend.

$>$ The smoke emissions were reduced by $20 \%$ and $40 \%$ for CBM 20 and CBM 40 blend respectively.

$>$ The slight increase of $5 \%$ and $8 \%$ of NOx emission is recorded for CBM 20 and CBM 40 respectively.

$>$ The combustion characteristics of country borage methyl ester and diesel blends are comparable with those of standard fuels. For the above results, the CBM 20 blend is superior when compared to other blends.

\section{REFERENCES}

1. Deepak Agarwal A and Lokesh Kumar B, "Performance evaluation of a vegetable oil-fuelled compression ignition engine" Renewable Energy 33 (2008) 1147-1156

2. Devan P.K and Mahalakshmi N.V, "Study of the performance, emission and combustion characteristics of a diesel engine using poon oil-based fuels " Fuel Processing Technology 90 (2009) 513-519

3. Huang Z H, Lu H B and Jiang DM , "Engine performance and emission of a compression ignition engine operating on the diesel-methanol blends" D10903 Mech 2004

4. Kajitani S Chen Z.L Knono M and RHEE K.T. "Engine performance and Exhaust characteristics of Direct-injection diesel engine operated with DME" SAE paper (1997), No.972973, 156

5. LeenusJesu Martin M and Edwin Geo V. “ A 
Comparative analysis methods to improve the performance of cotton seed oil fuelled diesel engine" Fuel 102 (2012) 372-378

6. MandeepKaur and Amjad Ali, "Lithium ion impregnated calcium oxide as nano catalyst for the biodiesel production from karanja and jatropa oils" Renewable Energy 36 (2011) 2866 to 2871

7. Misra R.D and Murthy M.S "Performance emission and combustion evaluation of soap nut oil-diesel blends in a compression ignition engine Fuel" Biomass abd Bio energy (902011) 2514-2518

8. NezahatBoz, NebahatDegirmenbasi B, Dilhan M. and Kalyon C., "Conversation of biomass to fuel Transesterification of vegetable oil to biodiesel using KF loaded nano-g-Al203 as catalyst applied Catalysis" Environment 89 (2009) 590-596

9. Nwafar O.M.I, Rice G. and Ogbonna A.I "Effect of advanced injection timing on the performance of rapsed oil in diesel engines" journal of renewable energy, Vol.21 (2003) 433-444

10. Shengyang Hu, Yanping Guan, Yun Wang and Heyon Han "Nano-magnetic catalyst $\mathrm{KF} / \mathrm{CaO}-\mathrm{Fe} 3 \mathrm{O} 4$ for biodiesel production Applied Energy 88 (2011) 2685-2690

11. SukumarPuhan A. and Vedaraman N., "Mahua oil methyl ester as biodiesel-preparation and emission characteristics" Biomass and Bioenergy 28 (2005) 87-93

12. Usta N. and Aydogan B., "Properties and quality verification of biodiesel produced from tabacco seed oil" Energy conversion and management 52 (2011) 2031-2039

13. YlfSchuchardta, RichardoSerchelia and RogerioMatheus Vargas., "Transesterification of crude oil: A Review." J.Braz., Chem. Soc., Vol.9,pp.199-210 (1998)

14. Yusuf Ali, Milford A. Hannd, "In-cylinder pressure characteristics of a DI heavy-duty diesel engine on Biodiesel Fuel." SAE paper No.971683.199

15. Muralidharan K, Vasudevan D, Sheeba K.N “ Performance emission and combustion characteristics of biodiesel fuelled variable compression ratio engine" ENERGY (2011) 5385- 5393 